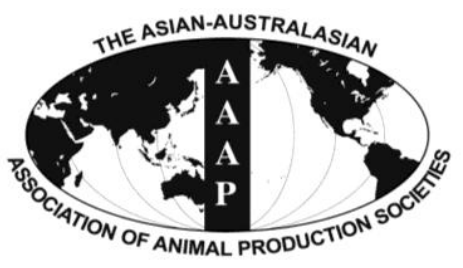

\title{
Effects of Dietary Selenium, Sulphur and Copper Levels on Selenium Concentration in the Serum and Liver of Lamb
}

\author{
Arlindo Saran Netto ${ }^{1, *}$, Marcus Antonio Zanetti ${ }^{1}$, Lisia Bertonha Correa ${ }^{1}$, Gustavo Ribeiro Del Claro ${ }^{1}$, \\ Márcia Saladini Vieira Salles ${ }^{2}$, and Flávio Garcia Vilela ${ }^{3}$ \\ ${ }^{1}$ Department of Animal Science, Faculty of Animal Science and Food Engineering, \\ University of São Paulo, Pirassununga-SP, 13635-900, Brazil
}

\begin{abstract}
Thirty-two lambs were distributed in eight treatments under $2 \times 2 \times 2$ factorial experiment to compare the effects of two levels of selenium $(0.2$ to $5 \mathrm{mg} / \mathrm{kg}$ dry matter [DM]), sulphur $(0.25 \%$ and $0.37 \%)$ and copper $(8$ and $25 \mathrm{mg} / \mathrm{kg} \mathrm{DM})$ levels on selenium concentration in liver and serum of lambs. A liver biopsy was done on all animals and blood samples were collected from the jugular vein prior to the beginning of the treatments. The blood was sampled every thirty days and the liver was sampled after 90 days, at the slaughter. Increasing differences were noticed during the data collection period for the serum selenium concentration, and it was found to be $0.667 \mathrm{mg} / \mathrm{L}$ in animals fed with $5 \mathrm{mg} \mathrm{Se} / \mathrm{kg}$ DM and normal sulphur and copper concentrations in their diet. However, a three-way interaction and a reduction of selenium concentration to $0.483 \mathrm{mg} / \mathrm{L}$ was verified when increasing copper and sulphur concentration levels to $25 \mathrm{ppm}$ and $0.37 \%$ respectively. The liver selenium concentration was also high for diets containing higher selenium concentrations, but the antagonist effect with the increased copper and sulphur levels remained, due to interactions between these minerals. Therefore, for regions where selenium is scarce, increasing its concentration in animal diets can be an interesting option. For regions with higher levels of selenium, the antagonistic effect of interaction between these three minerals should be used by increasing copper and sulphur dietary concentrations, thus preventing possible selenium poisoning. (Key Words: Selenium, Sulphur, Copper, Nutrition, Sheep)
\end{abstract}

\section{INTRODUCTION}

In ruminants, the highest degree of selenium absorption occurs in the small intestine, mainly in the duodenum. Selenium is less absorbed by ruminants than by monogastrics, due to the selenite reduction to insoluble compounds in the rumen (Levander, 1986). After absorbed, Se is carried in the plasma associated to selenocystine until it moves to the tissues (Deagen et al., 1987). The absorbed

* Corresponding Author: Arlindo Saran Netto. Tel: +55-1935654039, Fax: +55-19-35654047, E-mail: saranetto@usp.br

${ }^{2}$ Regional Poles of technological development of agribusiness APTA, Ribeirão Preto-SP, 14030-670 Brazil.

${ }^{3}$ Department of Nutrition and Animal Production, School of Veterinary Medicine and Animal Science, University of São Paulo, Pirassununga-SP, 13635-900 Brazil.

Submitted Dec. 14, 2013; Revised Jan. 30, 2014; Accepted Feb. 19, 2014 selenium is stored mainly in the kidneys and liver, besides other tissues such as the spleen and pancreas. When the dietary supply has low selenium concentration, the kidneys will store a higher amount than the liver. However, when the diet has high selenium concentration, the liver will store more than the kidneys (Koenig et al., 1997).

The main routes of excretion of selenium are through faeces, urine and breathing, since the quantity and distribution of the selenium excreted depends on the level of ingestion, dietary composition and the presence of a Se antagonist (NRC, 2007). When selenium is supplied orally, higher levels will be excreted through faeces, since microorganisms in the rumen will transform Se into unavailable compounds. However, when injected, the excretion occurs mainly through the urine.

According to Langlands et al. (1984), between $4 \%$ and $9 \%$ of the total of Se in sheep can be found in the liver and 
it tends to have the highest selenium concentration among all tissues. Therefore, liver selenium concentration is used to measure Se levels, even though large quantities can be found in the muscle. In an article about Selenium bioavailability, Fairweather-Tait (1997) mentions experiments with rats, which demonstrated that selenomethionine is absorbed by active transport together with methionine. Selenite is absorbed by simple diffusion process, selenate by a mechanism involving co-transport with sodium ions and influenced by sulphur, and selenocysteine, which shares an active transport mechanism with basic amino acids. Consequently, studies involving minerals and their interactions must also consider the ways that these minerals are administrated.

Selenium absorption, retention and distribution in the organism, as well as the quantity, configuration and excretion routes will vary, among other factors, according to its chemical formula, the quantity ingested and the time receiving a set Se level. Selenium is an element that has a very small margin between demand levels and toxicity. Dietary levels below $0.1 \mathrm{mg} / \mathrm{kg}$ dry matter (DM) is considered insufficient, and above $2 \mathrm{mg} / \mathrm{kg}$ DM can be toxic (Gierus, 2007). However, in ruminants, the rumen microbial activity influences the way that it reaches the small intestine for absorption, reducing the risk of poisoning (Cristaldi et al., 2005). The objective of this research was to verify the effects of dietary selenium levels and its interaction with copper and sulphur levels in lambs.

\section{MATERIAL AND METHODS}

This experiment was carried at the Animal Science and Food Engineering College of Pirassununga-SP, Brazil. Thirty two lambs (1/2 Ile de France $\times 1 / 2$ Ideal), with three months of age, weighing $23 \mathrm{~kg}$, were wormed after arriving on Campus. They were brought from the same property, so as to avoid possible variations coming from different management systems, with special attention to breed, age and weight. After a 14-day adaptation period of accommodation and feed, the animals were transferred to metabolic cages with individual drinkers and feeders in a sheltered area.

Before the beginning of the experiment, a biopsy was performed on animals to collect liver tissue for mineral analysis. Every 28 days, they were weighed and blood was collected from the jugular vein into vacutainers to determine the concentration of these minerals. Serum was separated by centrifugation, stored in identified flasks and immediately frozen at $-20^{\circ} \mathrm{C}$. The blood collected to analyse hematocrit level was kept in anti-coagulating tubes and analysed in the same day using the micro-hematocrit method. In the end of the experiment, the animals were euthanised and the livers were collected to determine selenium content. The collected tissues were washed with distilled water, identified, stored in plastic bags and frozen at $-20^{\circ} \mathrm{C}$.

The treatments were defined with two Se levels, two $\mathrm{S}$ levels and two $\mathrm{Cu}$ levels in dry matter and the composition of the basal diet is presented (Table 1). The water was analyzed and it revealed the following mineral composition $(\mathrm{mg} / \mathrm{L}): \mathrm{Ca} 10.76 ; \mathrm{Cu} 0.14 ; \mathrm{Fe}<0.02 ; \mathrm{p}<0.01 ; \mathrm{Mn}<0.003$; Total $\mathrm{N}<0.1$; K 1.75; Na 2.85; Zn 0.105. The vitamins and mineral mix were formulated specifically for this project and weighed with a precision balance, aiming for higher control and a secure and consistent ingestion of these nutrients. During the experimental period, the animals received water ad libitum and a formulated ration according to NRC (2007). The diets varied in sulphur, copper and selenium concentrations and, according to the NRC (2007), in some treatments, almost the maximum level (close to poisoning) was attained. Having limited information on the three-way interaction between these minerals, it was

Table 1. Composition of the basal diet (dry matter ) and treatment description

\begin{tabular}{|c|c|c|c|c|c|}
\hline Ingredients and nutrients & $(\mathrm{g} / 100 \mathrm{~g})$ & $\begin{array}{l}\text { Treatment } \\
(\mathrm{Se} / \mathrm{Cu} / \mathrm{S})\end{array}$ & $\begin{array}{c}\text { Selenium } \\
(\mathrm{mg} / \mathrm{kg} \mathrm{DM})\end{array}$ & $\begin{array}{c}\text { Copper } \\
(\mathrm{mg} / \mathrm{kg} \mathrm{DM})\end{array}$ & Sulphur (\%) \\
\hline Ground corn & 54.70 & $\mathrm{C}=0.2 / 8 / 0.25$ & 0.2 & 8.0 & 0.25 \\
\hline Extruded soybean & 18.00 & $\mathrm{~T} 1=5 / 8 / 0.25$ & 5.0 & 8.0 & 0.25 \\
\hline Cottonseeds hulls & 25.00 & $\mathrm{~T} 2=0.2 / 8 / 0.37$ & 0.2 & 8.0 & 0.37 \\
\hline Limestone & 1.30 & $\mathrm{~T} 3=5 / 8 / 0.37$ & 5.0 & 8.0 & 0.37 \\
\hline Minerals & 1.00 & $\mathrm{~T} 4=0.2 / 25 / 0.25$ & 0.2 & 25.0 & 0.25 \\
\hline Nutrients by analysis & & $\mathrm{T} 5=0.2 / 25 / 0.37$ & 0.2 & 25.0 & 0.37 \\
\hline Crude protein $(\%)$ & 16.7 & $\mathrm{~T} 6=5 / 25 / 0.25$ & 5.0 & 25.0 & 0.25 \\
\hline Ether extract (\%) & 6.4 & $\mathrm{~T} 7=5 / 25 / 0.37$ & 5.0 & 25.0 & 0.37 \\
\hline $\operatorname{NDF}(\%)$ & 29.5 & & & & \\
\hline $\operatorname{ADF}(\%)$ & 23.7 & & & & \\
\hline Selenium $\mathrm{mg} / \mathrm{kg}$ & 0.07 & & & & \\
\hline Copper mg/kg & 5.1 & & & & \\
\hline
\end{tabular}

DM, dry matter; NDF, neutral detergent fiber; ADF, acid detergent fiber. 
decided to use a range of levels for these minerals. Sulphur supplement was provided as flowers of sulphur, selenium as sodium selenite and copper as copper sulphate. They were added to a pre-mineral mix and subsequently mixed with the other ingredients, making it into a complete feed.

Drinking water was analysed to determine levels of selenium, copper and sulphur. Feed was also analysed to establish levels of DM, crude protein, ether extract, neutral detergent fibre, acid detergent fibre, ash, calcium and phosphorus (AOAC, 1990). The selenium analysis was done after the humid nitric-perchloric acid digestion and the fluorometric reading (Olson et al., 1975), a technique which according to Stowe and Herdt (1992) may provide more adequate results for laboratorial comparrison. For the analysis, all tissues were defrosted, a small portion was removed from exactly the same region of the organ and separated, washed with distilled deionised water, dried using disposable paper towels and weighed using a precision balance. The results were based on its original matter. To attain dry matter results, a small fragment of every tissue was taken, cleaned and weighed and put into an oven at $105^{\circ} \mathrm{C}$ for 24 hours and placed into a dessecador until it reached room temperature and weighed once again. The serum was defrosted and volumetric pipettes were used to extract two millimetres for analysis. Sulphur levels were determined using turbidimetry and "Flow Injection Analysis" and copper levels by spectrophotometry of atomic absorption (Perkin Elmer equipment).

The statistical design were in blocks based on animal weight. A $2 \times 2 \times 2$ factorial design was applied because of the two levels in which each mineral was studied, with four repetitions per treatment. The effects of selenium, copper and sulphur levels as well as selenium $\times$ copper $\times$ sulphur interaction were analyzed using Mixed procedure of SAS systen (SAS Institute Inc., Cary, NC, 2004). In the liver analysis, biopsy results were used as a covariable. The programme statistical was used for the response surface graphs. A $\alpha=0.05$ significance level was adopted for all analysed data.

\section{RESULTS AND DISCUSSION}

The selenium concentration (Table 2) observed in this research at the beginning of the experimental period can be considered normal according to Stowe and Herd (1992). There was no significant difference between treatments in serum selenium concentration in animals receiving $0.2 \mathrm{mg}$ $\mathrm{Se} / \mathrm{kg}$ DM during the experiment period, despite different dietary sulphur and copper levels in treatments. A similar result was obtained by Brisola (2000). For animals receiving $5 \mathrm{mg} \mathrm{Se} / \mathrm{kg} \mathrm{DM}$, independent of treatment with copper and sulphur, a difference in serum selenium concentration was noticed over time. Animals treated with $\mathrm{T} 1=5 / 8 / 0.25$ and $\mathrm{T} 6=5 / 25 / 0.25$, for 30 days after the beginning of the experiment, presented a higher selenium concentration compared to other animals. The same cannot be said for animals treated for 60 days with 5 ppm Se, 25 ppm $\mathrm{Cu} 0.37 \% \mathrm{~S}$, as they presented inferior serum concentration compared to the group of animals under the same daily quantity of $5 \mathrm{ppm}$. After 90 days, the animals under the 5 ppm Se, 8 ppm Cu, 0.37\% S and 5 ppm Se, 25 ppm $\mathrm{Cu}$ and $0.37 \% \mathrm{~S}$ treatment, presented a significant difference in selenium levels amongst themselves and inferior levels compared to the other two $5 \mathrm{ppm}$ selenium treatments.

Echevarria et al. (1988) verified a lamb's serum selenium concentration of $0.09 \mathrm{mg} / \mathrm{L}$ in the control group, using crossbred wethers with an average weight of $50 \mathrm{~kg}$ and diet contained $0.18 \mathrm{mg} \mathrm{Se} / \mathrm{kg}$ (DM basis). In the group supplemented with $9 \mathrm{mg} \mathrm{Se} / \mathrm{kg} \mathrm{DM}$, a concentration of 0.25 $\mathrm{mg} / \mathrm{L}$ was obtained only 30 days after beginning with supplementation. The serum selenium concentration presented a linear increase with dietary selenium level.

Henry et al. (1988), confirmed that by adding $6 \mathrm{mg}$ of $\mathrm{Se}$ in the form of sodium selenite/kg in the dry matter intake during 30 days produced an increase in serum selenium concentration of $0.09 \mathrm{mg} / \mathrm{L}$ to $0.22 \mathrm{mg} / \mathrm{L}$. These results were similar to the ones found in the present experiment during the same amount of time and to animals

Table 2. Selenium concentration in blood serum of lambs receiving different concentrations of sulfur, selenium and copper in diet

\begin{tabular}{|c|c|c|c|c|}
\hline \multirow{2}{*}{$\begin{array}{l}\text { Dietary treatments } \\
\left(\mathrm{Se} / \mathrm{Cu} / \mathrm{S}^{*}\right)\end{array}$} & \multicolumn{4}{|c|}{ Selenium concentration $(\mu \mathrm{g} / \mathrm{mL})$} \\
\hline & 0 day & 30 days & 60 days & 90 days \\
\hline $\mathrm{C}=0.2 / 8 / 0.25$ & 0.098 & $0.097^{\mathrm{c}}$ & $0.076^{\mathrm{c}}$ & $0.116^{\mathrm{d}}$ \\
\hline $\mathrm{T} 2=0.2 / 8 / 0.37$ & 0.093 & $0.095^{\mathrm{c}}$ & $0.086^{\mathrm{c}}$ & $0.102^{d}$ \\
\hline $\mathrm{T} 4=0.2 / 25 / 0.25$ & 0.093 & $0.097^{\mathrm{c}}$ & $0.094^{\mathrm{c}}$ & $0.121^{\mathrm{d}}$ \\
\hline $\mathrm{T} 5=0.2 / 25 / 0.37$ & 0.093 & $0.101^{\mathrm{c}}$ & $0.077^{\mathrm{c}}$ & $0.108^{\mathrm{d}}$ \\
\hline $\mathrm{T} 1=5 / 8 / 0.25$ & $0.078^{\mathrm{D}}$ & $0.218^{\mathrm{Ca}}$ & $0.386^{\mathrm{Ba}}$ & $0.667^{\mathrm{Aa}}$ \\
\hline $\mathrm{T} 3=5 / 8 / 0.37$ & $0.078^{\mathrm{D}}$ & $0.145^{\mathrm{Cb}}$ & $0.369^{\mathrm{Ba}}$ & $0.597^{\mathrm{Ab}}$ \\
\hline $\mathrm{T} 6=5 / 25 / 0.25$ & $0.086^{\mathrm{D}}$ & $0.186^{\mathrm{Ca}}$ & $0.356^{\mathrm{Ba}}$ & $0.697^{\mathrm{Aa}}$ \\
\hline $\mathrm{T} 7=5 / 25 / 0.37$ & $0.089^{\mathrm{D}}$ & $0.145^{\mathrm{Cb}}$ & $0.280^{\mathrm{Bb}}$ & $0.483^{\mathrm{Ac}}$ \\
\hline
\end{tabular}

Different letters on same column differ significantly $(\mathrm{p}<0.05)$. Different capital letters on same row differ significantly $(\mathrm{p}<0.05)$.

* Se and $\mathrm{Cu}(\mathrm{mg} / \mathrm{kg} \mathrm{DM})$ and $\mathrm{S}$ as $\%$. 
supplemented with $5 \mathrm{mg} \mathrm{Se} / \mathrm{kg}$ of feed. Van Ryssen et al. (1998) found plasma Se concentration at $0.054 \mathrm{mg} / \mathrm{L}$ at the beginning of the experiment and after supplementation with sodium selenite at $0.35 ; 0.88$ or $1.34 \mathrm{mg}$ of Se for 74 days, the concentration level increased to $0.125,0.150$, and 0.160 $\mathrm{mg} / \mathrm{L}$ respectively. There was no significant effect on plasma selenium concentration when $2 \mathrm{~g} / \mathrm{kg}$ of dietary sulphur was added.

Orden et al. (2000) administered a soluble glass bolus $(\mathrm{SBG})$ with cobalt $(\mathrm{Co})$, selenium $(\mathrm{Se})$ and copper $(\mathrm{Cu})$ to 50 Philippine goats. After 4 weeks, the treated goats showed an increased blood selenium $(0.28 \mu \mathrm{mol} / \mathrm{L}$ at baseline to 0.8 $\mu \mathrm{mol} / \mathrm{L}$ ), while in the untreated animals, the values were $0.27 \mu \mathrm{mol} / \mathrm{L}$ at baseline and $0.25 \mu \mathrm{mol} / \mathrm{L}$ after 4 weeks. The plasma $\mathrm{Cu}$ level of the treated animals also increased relative to untreated animals.

Aghwan et al. (2013), in an experiment with goats and supplementation with selenium and iodine, found increased concentration of these minerals in the blood compared to animals that were not supplemented. The selenium values were: $53.11,54.79,154.02$, and $137.00 \mu \mathrm{g} / \mathrm{L}$ for the animals that received the control treatment or $0.6 \mathrm{mg} / \mathrm{kg}$ of $\mathrm{I}, 0.6$ $\mathrm{mg} / \mathrm{kg}$ of Se and $0.6 \mathrm{mg} / \mathrm{kg}$ of both minerals, respectively.

In the work of Kumar et al. (2008), eighteen lambs were divided into three groups and were fed a control diet or supplemented with 0.15 or $0.30 \mathrm{mg} / \mathrm{kg}$ of sodium selenite. Both groups supplemented with selenium had increased levels of this mineral in plasma. In another work, Kumar et al. (2009) supplemented lambs with inorganic and organic selenium and also found a significant increase in the serum selenium level these animals.

Cows supplemented with Se had greater $(\mathrm{p}<0.01)$ whole blood Se concentration than cows receiving no supplemental Se (Gunter, 2013). Brennan et al. (2010), supplementing heifers with sodium selenite or organic selenium, also found increase of selenium concentration in the blood of supplemented animals compared to those not receiving supplementation.

Even though there are controversies in literature, through this research it can be observed that there is a threeway interaction between the minerals sulphur, selenium and copper and it exists for different serum selenium concentrations. With a higher dietary sulphur level $(0.37 \%)$ the increase of selenium level was less evident. This value was even less accentuated when there was an increase in dietary sulphur and copper levels of $0.37 \%$ and $25 \mathrm{ppm}$, respectively.

When analysing the Figure 1, 2, and 3 using statistical analysis, the antagonist effect between the increase in sulphur level and the accumulation of selenium in the liver was verified, as the increase in copper level contributed to a higher level of selenium accumulated in the liver. The threeway interaction was also quite significant $(\mathrm{p}<0.05)$, where

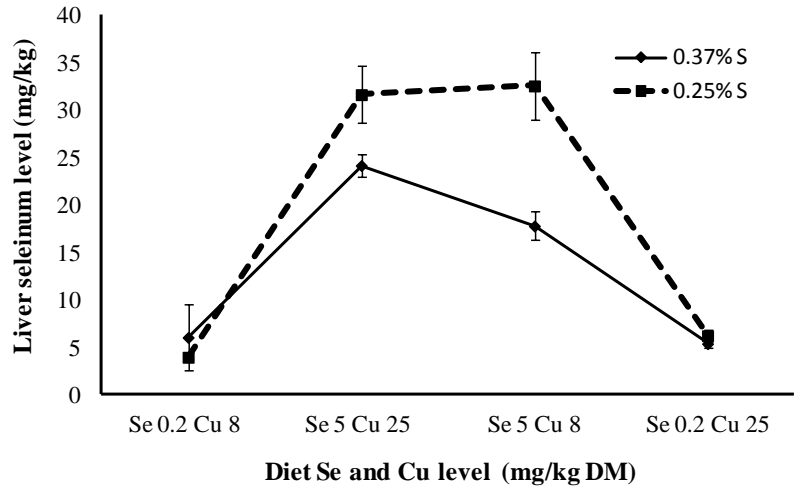

Figure 1. Liver selenium concentration of lambs with different levels of selenium and copper in the diet.

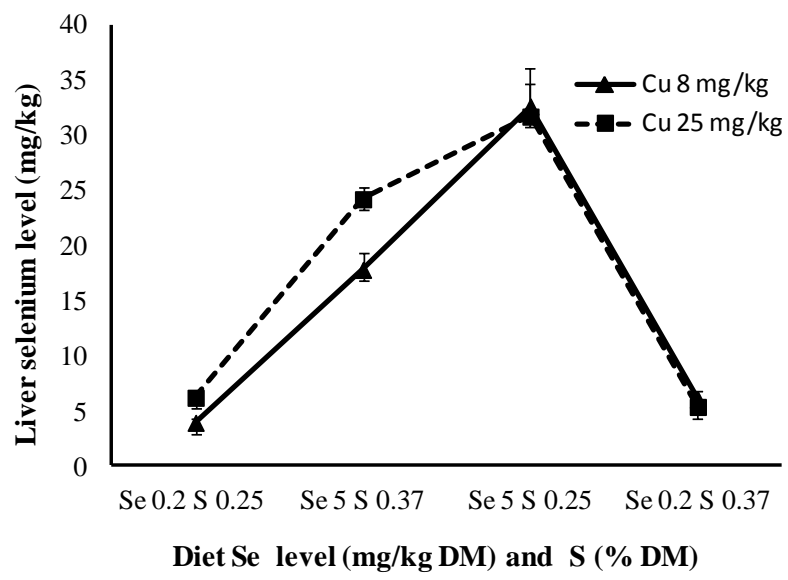

Figure 2. Liver selenium concentration of lambs with different levels of selenium and sulphur in the diet.

storage was less evident when selenium levels were high, even though copper level was low and sulphur was high.

The medium selenium values in the liver (dry base) are next to $5 \mathrm{mg} / \mathrm{kg}$ in animals treated with $0.2 \mathrm{mg} / \mathrm{kg} \mathrm{Se}$. This value is higher than the one obtained by Echevarria et al. (1988), $4.5 \mathrm{mg} / \mathrm{kg}$, using the same selenium values, although lower copper levels. By giving $5 \mathrm{mg} / \mathrm{kg}$ of selenium to lamb for 90 days, Brisola (2000), attained a

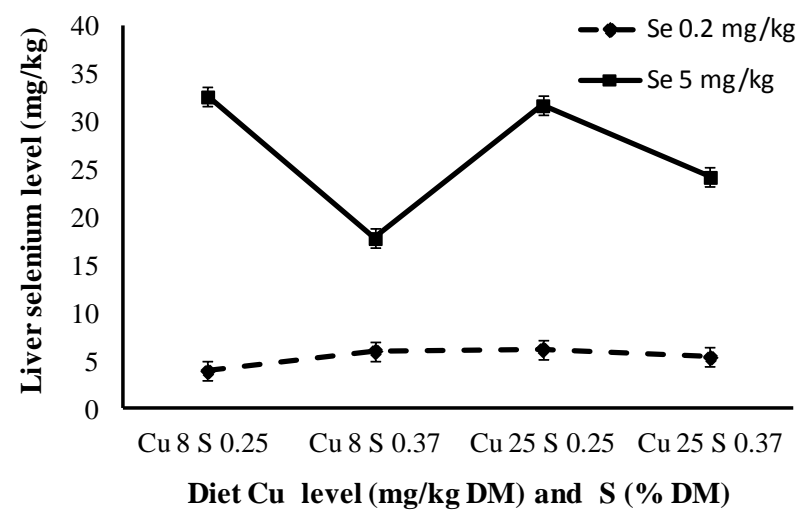

Figure 3. Liver selenium concentration of lambs with different levels of copper and sulphur in diet. 
selenium concentration of $40 \mathrm{mg} / \mathrm{kg}$ in the liver, higher to the $32 \mathrm{mg} / \mathrm{kg}$ obtained in this experiment.

Van Ryssen et al. (1998), verified that even rumen bacteria presented lower Se concentration when suplemented with dietary sulphur. Based on these findings, it is possible to confirm the effects of sulphur over selenium and that increasing copper intake results in higher selenium concentrations in lamb livers. White and Somers (1977) and Hartmann and Van Ryssen (1997) results confirm the synergism between copper and selenium. In Deol et al. (1994) research, as well as this one, it was observed that a higher level of hepatic selenium was a consequence of elevated copper levels.

To avoid selenium intoxication, Underwood (1981) proposed the use of antagonistic elements, aiming to reduce their accumulation in tissue as well as its absorption in the digestive tract. It can be confirmed in conjunction to most papers, that sulphur acts as an antagonist to selenium and is responsible for minimizing liver selenium concentration. It can be used as an antagonist to avoid possible intoxication in certain regions where there is high selenium concentration in forage, whilst a high level of copper might cause certain problems given that it contributes to a higher accumulation of liver selenium. High dietary sulphur and copper concentrations are an interesting alternative, considering the three-way interaction between the elements.

\section{CONCLUSION}

Serum selenium concentration increases in relation to time on all selenium supplementation treatments and no significant differences are found in serum selenium concentration in animals given $0.2 \mathrm{mg} \mathrm{Se} / \mathrm{kg} \mathrm{DM}$, despite the dietary levels of sulphur and copper. The present study verified the effects of a three-way interaction. During treatments with $5 \mathrm{mg} \mathrm{Se} / \mathrm{kg}$ of DM, the increase in dietary copper and sulphur levels reduce the concentration of selenium in blood serum. The increase of dietary selenium concentration results in higher liver selenium concentration. A reduced effect will occur when using copper and sulphur in the diet, due to the three-way interaction between the minerals. Recommendations as to the amount of selenium, copper and sulphur in animal diet have to be revised, since the interaction between dietary components must be taken into consideration, as some studies have highlighted.

\section{REFERENCES}

Aghwan, Z. A., A. Q. Sazili, and A. R. Alimon. 2013. Blood haematology, serum thyroid hormones and glutathione peroxidase status in Kacang goats fed inorganic iodine and selenium supplemented diets. Asian Australas. J. Anim. Sci. 26:1577-1582.
AOAC. 1990. Official Methods of Analysis. 15 edn. Association of Oficial Analytical Chemists. Arlington, VI, USA. p. 128.

Brennan, K. M., W. R. Burris, J. A. Boling and J. C. Matthews. 2010. Effects of selenium source on blood selenium content, blood cell counts and peripheral blood mononuclear cell mRNA profiles in maturing beef heifers. FASEB J. 24 (Meeting Abstract Supplement) 916.4.

Brisola, M. L. 2000. Effects of Increasing Levels of Sulfur in Diets for Lambs Subjected to Toxic Levels of Selenium. PhD Thesis, University of São Paulo, São Paulo, Brazil. 89 p.

Cristaldi, L. A., L. R. McDowell, C. D. Buergelt, P. A. Davis, N. S. Wilkinson, and F. G. Martin. 2005. Tolerance of inorganic selenium in wether sheep. Small Rumin. Res. 56:205-213.

Deagen, J. T., J. A. Butler, and M. A. Belstein. 1987. Effects of dietary selenite, selenocystine and selenomethionine on selenocysteine lyase and glutathione peroxidase activities and on selenium levels in tissues. J. Nutr. 117:91-98.

Deol, H. S., J. M. Howell, and P. R. Dorling. 1994. Effect of the ingestion of heliotrope and copper on the concentration of zinc, selenium and molybdenum in the liver of sheep. J. Comp. Pathol. 110:303-307.

Echevarria, M. G., P. R. Henry, C. B. Ammerman, and P. V. Rao. 1988. Effects of time and dietary selenium concentration as sodium selenite on tissue selenium uptake by sheep. J. Anim. Sci. 66:2299-2305.

Fairweather-Tait, S. J. 1997. Bioavailability of selenium. Euro. J. Clin. Nutr. 51 (Suppl.1):s20-s23.

Gierus, M. 2007. Organic and inorganic sources of selenium in the nutrition of dairy cows: Digestion, absorption, metabolism and requirements. Ciên. Rural. 37:1212-1220.

Gunter, S. A., P. A. Beck, and D. M. Hallford. 2013. Effects of supplementary selenium source on the blood parameters in beef cows and their nursing calves. Biol. Trace. Elem. Res. 152:204-211.

Hartman, F. and J. B. J. Van Ryssen. 1997. Metabolism of selenium and copper in sheep with and without sodium bicarbonate suplementation. J. Agric. Sci. 128:357-364.

Henry, P. R., M. G. Echevarria, C. B. Ammerman, and P. V. Rao. 1988. Estimation of the relative biological availability of inorganic selenium sources for ruminants using tissue uptake of selenium. J. Anim. Sci. 66:2306-2312.

Koenig, K.M., L. M. Rode, R. D. H. Cohen, and W. T. Buckley. 1997. Effects of diet and chemical form of selenium on selenium metabolism in sheep. J. Ani. Sci. 75:817-827.

Kumar, N., A. K. Garg, V. Mudgal, R. S. Dass, V. K. Chatuverdi, and V. P. Varshney. 2008. Effect of different levels of selenium supplementation on growth rate, nutrient utilization, blood metabolic profile, and immune response in lambs. Biol. Trace Elem. Res. 126 (Suppl.):S44-S56.

Kumar, N., A. K. Garg, R. S. Dass, V. K. Chatuverdi, V. Mudgal, and V. P. Varshney. 2009. Selenium supplementation influences growth performance, antioxidant status and immune response in lambs. Anim. Feed Sci. Technol. 153:77-87.

Langlands, J. P., J. E. Bowles, G. E. Donald, and A. J. Smith. 1984. Deposition of copper, manganese, selenium and zinc in Merino sheep. Aust. J. Agric. Res. 35:701-707

Levander, O. A. 1986. Selenium. In: Trace elements in Human and Animal Nutrition (Ed. W. Mertz). Academic Press, New York. 2:209-279. 
National Research Council. 2007 Nutrient Requirements of Small Ruminants. 7 ed. National Academic Press, Washington, DC, USA. 384 p.

Olson, O. E., I. S. Palmer, and E. E. Cary. 1975. Modification of the official fluorimetric method for selenium in plants. J. Assoc. Agric. Chem. 58:117-121.

Orden, E. A., A. B. Serra, S. D. Serra, K. Nakamura, L. C. Cruz, and T. Fujihara. 2000. Direct effects of copper and selenium supplementation and its subsequent effects on other plasma minerals, body weight and hematocrit count of grazing philippine goats. Asian Australas. J. Anim. Sci. 13:323-328.

SAS Institute Inc. 2004. SAS Stat Guide, Release 6.03 Edition. Cary, NC, USA. 1028 p.
Stowe, H. D. and T. H. Herdt. 1992. Clinical assesment of selenium status of livestock. J. Anim. Sci. 70:3928-3933.

Underwood, E. J. 1981. The Mineral Nutrition of Livestock, 2nd ed. Commonwealth Agricultural Bureaux, Buckinghamshire, UK. $210 \mathrm{p}$.

White, C. L. and M. Somers. 1977. Sulphur-selenium studies in sheep I. The effects of varying dietary sulphate and selenomethionine on sulphur, nitrogen and selenium metabolism in sheep. Aust. J. Biol. Sci. 30:47-56.

Van Ryssen, J. B. L., P. S. M. Van Malsen, and F. Hartmann. 1998. Contribution of dietary sulphur to the interaction between selenium and copper in sheep. J. Agric. Sci. 130:107-114. 